\title{
DETERMINANTS AND EFFICIENCY LEVEL OF CAPITAL GOODS IMPORTS IN INDONESIA: EXPLORING USING GRAVITY MODELS
}

\author{
Sakti Prabowo ${ }^{1)}$ \\ 1) bowo_saktie@gmail.com, Polytechnic of State Finance STAN, Indonesia
}

\begin{abstract}
The study aims to investigate the significant factors and efficiency of capital goods imports in Indonesia. This study applies the stochastic frontier gravity approach (SFGA) to explore Indonesia's capital goods import values. The results suggest that there are positive impacts of some factors on the capital goods imports, including the GDP and population of the trading partners, distance, and regional cooperation such as the Free Trade Agreement (FTA). However, some factors, including the exchange rate and some global crises have significant negative impacts on the capital goods imports. The positive effects of FTA on capital goods imports may contribute to a reduction in the behind-the-border constraints. Furthermore, the trade efficiency resulting from the model may suggest that there is still a gap between potential and actual trade affected by the country-specific constraints, implying the requirement to investigate the appropriate reforms in Indonesia to reduce such constraints.

Keywords: Economic Growth, Capital Goods Imports, Country-Specific Constraints
\end{abstract}

Abstrak

Penelitian ini bertujuan untuk mengetahui faktor signifikan dan tingkat efisiensi impor barang modal di Indonesia. Penelitian ini menggunakan pendekatan stochastic frontier gravity (SFGA) untuk mengeksplorasi nilai impor barang modal Indonesia. Hasil penelitian menunjukkan terdapat dampak positif dari beberapa faktor terhadap impor barang modal, antara lain PDB dan populasi mitra dagang, jarak, dan kerjasama regional seperti Free Trade Agreement (FTA). Namun, beberapa faktor, seperti nilai tukar dan beberapa krisis global berdampak negatif signifikan terhadap impor barang modal. Efek positif FTA pada impor barang modal dapat berkontribusi pada pengurangan hambatan di belakang perbatasan. Selain itu, efisiensi perdagangan yang dihasilkan dari model tersebut dapat menunjukkan bahwa masih ada kesenjangan antara perdagangan potensial dan aktual yang dipengaruhi oleh kendala khusus negara, yang menyiratkan kebutuhan untuk menyelidiki reformasi yang tepat di Indonesia untuk mengurangi kendala tersebut.

Kata kunci: Pertumbuhan Ekonomi, Impor Barang Modal, Kendala Perbatasan Negara

\section{INTRODUCTION}

In developing economies, capital goods imports may have crucial roles in enhancing economic growth. It is because capital products may embody technology, which may result in a dynamic gain from trade compared to other sectors. During the period 1990-2018, the capital goods imports in Indonesia show an increasing pattern. However, the economic growth is relatively stagnant. Therefore, it is crucial to identify whether the capital good import values have achieved their potential level or not to gain optimum economic growth. According to Kalirajan (2007), some factors, which may hamper the potential trade between economies are called country-specific constraints. These constraints may include the poor quality of institutions or trade policy. To overcome such constraints, having a regional trade agreement may help to reduce the trade constraints between countries. Currently, Indonesia joins some regional trade cooperation, such as the ASEAN-plus-one free trade area (FTA). Thus, this study will analyze the major factors, including country-specific constraints and regional cooperation, which determine the values of capital goods imports, and also the efficiency of the capital good imports of Indonesia. The method used to examine the purpose of the study is the stochastic frontier gravity model (SFGM).

This study will consist of four parts. In the first section, this paper will present the literature review, including the roles of global trade and capital imports in enhancing economic performances. The second section will explain the method applied in the study. Next, the third part will present and the estimation results and discussion, and the last part will present the conclusion and suggestion based on the result analysis. 


\section{JURNALKU}

Volume 1 No. 3, September 2021

\section{LITERATURE REVIEW}

Global trade may boost the economic growth of the economies as it may result in static and dynamic gains. Based on the Ricardo Model, the static gains may derive from the comparative advantage. According to (Thirlwall, 2001), economies may determine their specialization in commodities based on labor productivity and opportunity cost called comparative advantage. This can optimize resources allocation, which in turn contributes to maximizing the output, and thus improve economic performance. Next, according to the Heckscher-Ohlin model, the comparative advantage can be determined by the productivity of other endowments such as land and capital. The second benefit, which is the dynamic gains from trade, may include the larger markets and technology and ideas diffusion. This may then result in more specialization, which can enhance human capital accumulation resulting in the innovation required to achieve economic growth (Thirlwall, 2001).

Specifically, capital goods imports may have vital roles in promoting economic growth in countries. According to Thirlwall (2001), capital imports may speed up the growth rate of output. It assumes that the loss of domestic savings to pay interest is lower than the new inflow of international capital. Furthermore, capital goods imports may have positive roles on the growth rate of output even if the new foreign capital is the same as the interest rate. However, there is an argument that the capital imports may enhance the capital-output ratio indicating the capital productivity gets lower and thus hamper the domestic saving. Such circumstances may suggest that a large portion of capital is used for consumption instead of investment.

Figure 1. Indonesia's total capital good imports and economic growth, 1990-2018

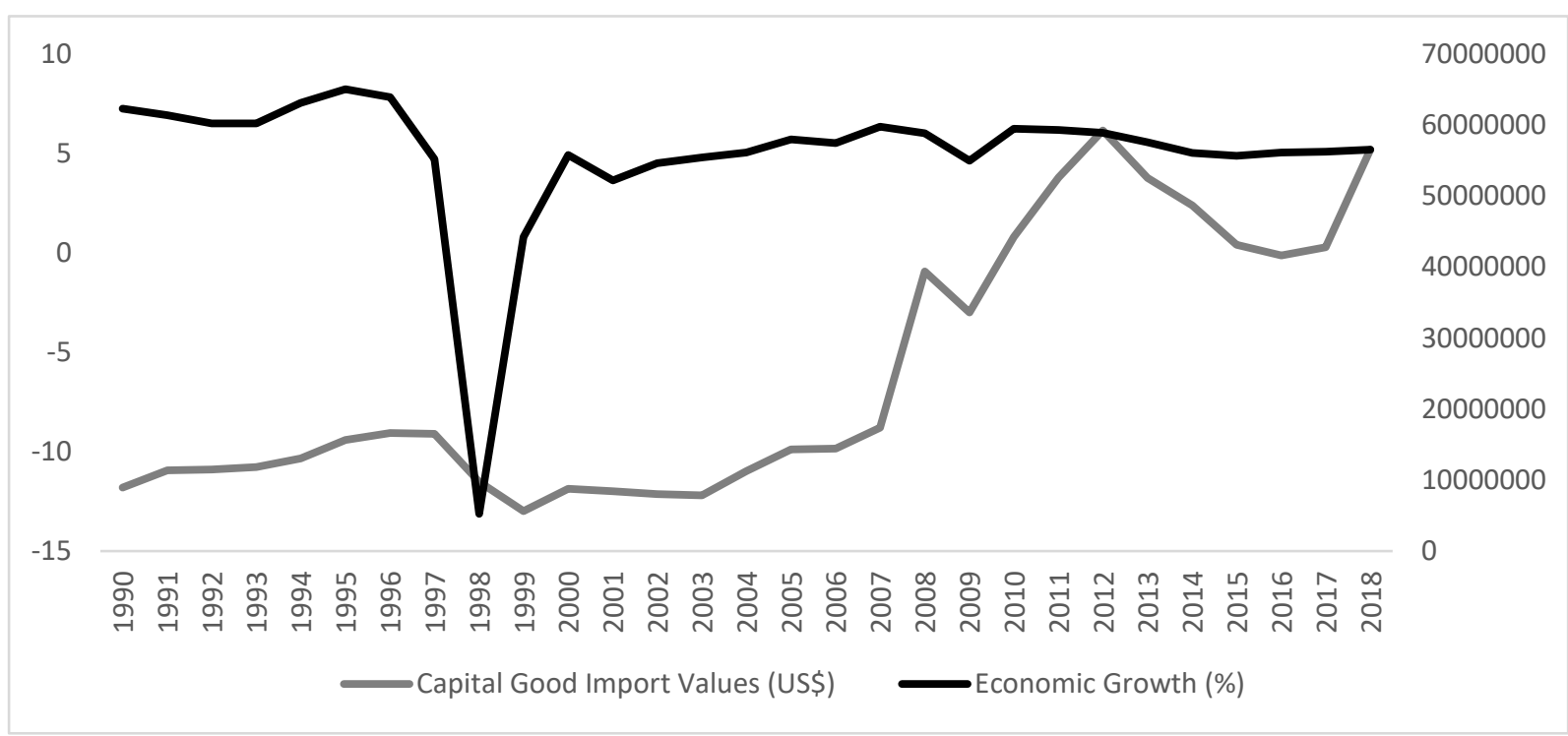

Sources: WITS (2021)

Between 1990 and 2018, Indonesia's total capital goods imports show an increasing pattern as shown in Figure 1 (World Bank, 2020). The financial crisis in 2008 and 2009 may have reduced the import values. However, the economic growth in Indonesia in the same period shows a different figure. Indonesia experienced a sharp fall in growth in 1998 due to the financial crisis, but it raised in 1999 and got stagnant until 2018. This figure may suggest that the growing pattern in capital goods imports may be still less effective in boosting economic growth. Therefore, the identification of whether the imports potential level has already been achieved or not should be investigated. 


\section{JURNALKU}

Volume 1 No. 3, September 2021

There are some factors influencing trade activities, including capital goods imports. One of such factors is called the country-specific constraints, which may include social, political, and institutional constraints. The government distortion may indicate these country specificconstraints. According to Kalirajan (2007), some studies show that the country-specific constraints may impede the trade between economies and then result in the gap in potential and actual trade flow. Miankhel et al. (2014) show that country-specific constraints are crucial reasons to explain the occurrence of differences between actual and potential exports in Australia.

Indonesia may impose country-specific constraints such as regulatory restrictions, particularly in trade and investment. The World Bank (2018) suggests that the tariffs and nontariff measures (NTMs) imposed on the capital goods imported by Indonesia can make the production cost increase and the quality of production input lowering. Furthermore, the reduction in capital goods imports may then hamper the technology absorption, which may impede economic efficiency. Therefore, the presence of the country-specific constraints indicated by the difference between potential and actual trade flow will be crucial to be identified.

The regional trading agreement may contribute to a decline in country-specific restrictions. According to Kalirajan (2007), Australia experienced an increase in exports potential after having a regional trading agreement with the IOR-ARC economies, indicating a reduction in trade constraints. In terms of regional cooperation, Indonesia has engaged in some regional trade agreements. Indonesia has joined the ASEAN-Free Trade Agreement (AFTA) since 1992. This agreement includes a reduction in tariffs, indicating a reduction in trade constraints (Badan Kebijakan Fiskal, 2012).

Figure 2. Indonesia's capital product imports from 6 (six) ASEAN economies (selected), 1990-2018

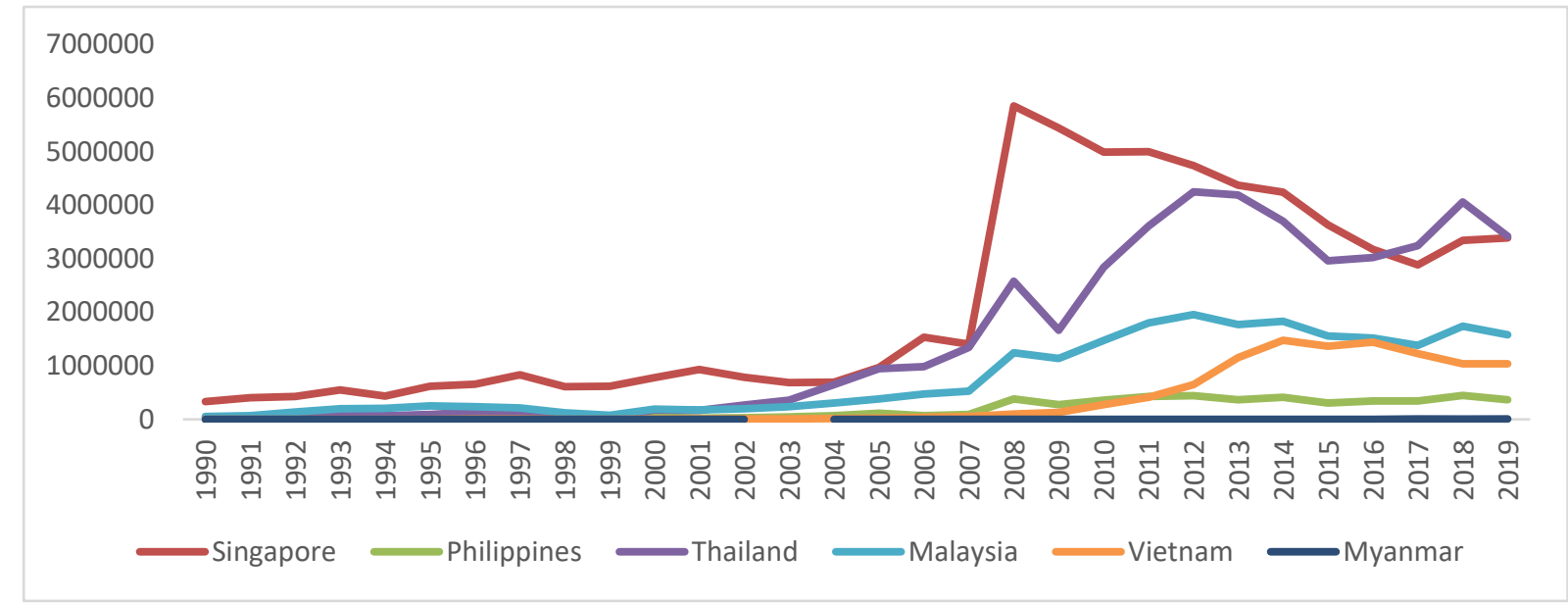

Sources: WITS (2021)

Figure 2 indicates Indonesia's capital goods import values from six ASEAN countries, which are Singapore, Philippines, Thailand, Malaysia, Vietnam, and Myanmar, have been increased during 1990-2018 (World Bank, 2020). The increases in capital goods imports also occur from ASEAN-plus-one countries, which include China, Japan, Korea, India, Australia, and New Zealand. Among these countries, Japan is the country with the most significant capital goods import values, while New Zealand is the lowest one (Figure 2). 


\section{JURNALKU}

Volume 1 No. 3, September 2021

\section{Figure 3. Indonesia's capital good imports from ASEAN-plus-one FTA countries,} 1990-2018

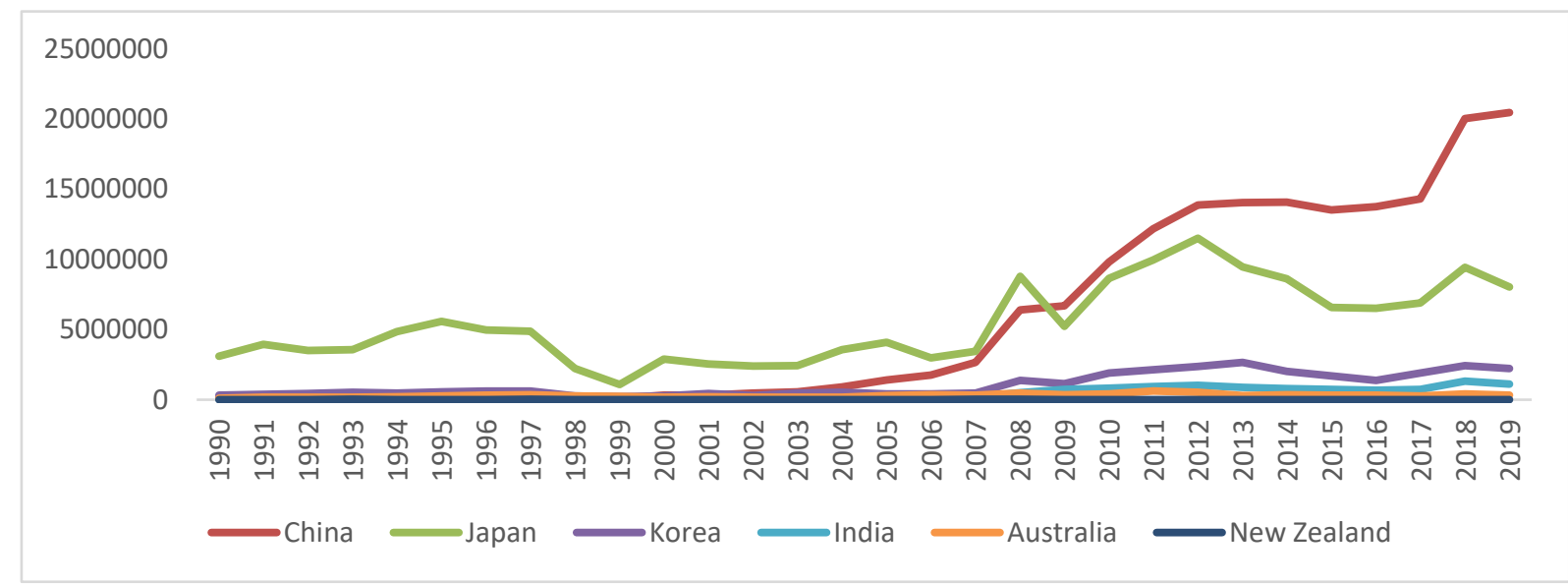

Sources: WITS (2020)

According to Frankel \& Rose (2000), regional cooperation through FTA can promote trade flows between country members. Furthermore, Wong et al. (2017) suggest that regional agreement (AFTA) has resulted in a larger amount of trade creation effects in imports than diversion effects. Therefore, regional cooperation may boost trade flows among member economies by eliminating tariff and non-tariff constraints.

\section{METHOD}

This study is aimed to explore the significant determinant factors and efficiency level of capital good import values in Indonesia using the SFGM Model. At first, the model introduced by Tinbergen was used to examine the global trade using the structure as below:

$$
X_{i j t}=\alpha_{0} G D P_{i}^{\alpha_{1}} G D P_{j}^{\alpha_{2}} D I S T_{i j}^{\alpha_{3}} D B^{\alpha_{4}} D P^{\alpha_{5}}
$$

The variable Xij represents exports from economy $i$ to $j$, GDPi and GDPj represent the GDP of economy $i$ and $j$, DISTij indicates is the distance between economy $i$ and $j$, DB indicates a dummy variable for trading partners, and DP indicates a dummy variable for a trade tariff area membership, which is preferable.

It is very crucial to formulate the right specification of gravity models and their estimation as well. According to Kalirajan (2008), the basic gravity models examine the relationship of trade flows between two countries with the GDP, population, and regional distance. But, the model has incorrect specifications and estimation. This is because other factors are influencing the trade flow, which are country-specific effects, including the social and economic issues, the infrastructure availability, and political institutions (Kalirajan, 2008). Therefore, this may imply that the estimation of the model is biased and inconsistent since it may suffer from the omitted variable issues. as below:

Therefore, Kalirajan (2008) suggests estimating the trade flows using the gravity model

$$
\ln X_{i j}=\ln f\left(Z_{j}, \beta\right) \exp ^{\left(v_{i}-u_{i}\right)}
$$

where $X i j$ indicates the real export values from economy i to j. In $f(Z j, \beta)$ includes variables determining the potential exports from economy $i$ to $j$. These variables may include economic size, number of people, and distance between the two countries. $\beta$ indicates the unknown measures vector. Next, the term $u_{i}$ is the non-negative random parameter contributing to the gap between actual and potential exports, which shows the effects of the country-specific 


\section{JURNALKU}

Volume 1 No. 3, September 2021

constraints. The component of $v_{i}$ includes impacts of omitted variables and errors of measurements which distribute across the unit analysis.

$$
T R E_{i j}=\exp \left(-u_{i j}\right)(3)
$$

According to the stochastic frontier gravity approach (SFGA) model, the formula above may calculate the trade efficiency for export. The $\exp (\mathrm{u})$ indicates the trade gap between actual and potential exports. The value is 0 when the trade gap does not exist, and 1 when the trade gap exists.

Previous studies have been conducted to identify the determinants of trade using the gravity models. Alam et al. (2009) study Bangladesh imports with eight main trading partners applying the gravity theory. The results show that the imports of Bangladesh can fulfill the gravity theory. There are positive impacts of geographical distance and trading partners' GDP. On the other hand, other factors have a mixed relationship with the imports of Bangladesh. This finding is relatively similar to other studies. Ma (2015) investigates the factors determining U.S. imports from its 50 primary trading partners using a gravity model. The paper finds that there are significant positive impacts on U.S. imports of trade partners' GDP and geographical distance.

Using gravity models to analyze the determinants of manufacturing trade flows in Indonesia, Wahyuningsih (2021) suggests that the Indonesia GDP and the ASEAN economic integration have statistically positive significant impacts on the trade flows of manufacturing sectors. In contrast, some factors, which are the tariff, exchange rate, and geographical distance have a significant adverse effect on manufacturing trade flows. Some other studies reveal relatively similar results. Wahyudi \& Anggita (2015) suggest that the determinants of Indonesian bilateral trades include Constant GDP, Per Capita GDP, geographical distance indicating transportation cost, and Real Effective Exchange Rate. Next, Kahfi (2016) shows that Indonesia's manufacturing exports have a significant relationship with the exchange rate, the economic size (GDP), the two countries' distance, and trade tariffs. Moreover, Indonesian merchandise export flows with 62 trading partners is significantly positively affected by GDP and population, then negatively affected by bilateral distance (Noviyani et al., 2019)

\section{ESTIMATION RESULTS AND DISCUSSIONS}

Table 1 Variables, Units, and Data Sources

\begin{tabular}{lll}
\hline VARIABLES & UNITS & DATA SOURCES \\
\hline Capital Good Imports & US\$ & WITS \\
\hline GDPcu & Current US\$ & WDI \\
\hline Population & People & WDI \\
\hline Distance & KM & CEPII \\
\hline Border & - & CEPII \\
\hline Tariff & $\%$ & WITS \\
\hline Exchange Rate & LCU/ US\$ & WDI \\
\hline $\begin{array}{l}\text { Free Trade Agreement } \\
\text { (FTA) }\end{array}$ & - & The Indonesia Finance Ministry \\
\hline
\end{tabular}

The data set used in the study is the capital good imports of Indonesia to 51 major trading partners shown in Appendix 1. Table 1 shows all variables analyzed in the study and Table 2 presents the summary statistics for all variables covered in the study. According to the value variance inflation factor (VIF), since the VIF value for all variables are less than 10, it then shows that multicollinearity among variables does not exist. 
Table 2 Summary Statistics

\begin{tabular}{|c|c|c|c|c|c|}
\hline VARIABLE & $\begin{array}{lr}\text { NUMBER } & \text { OF } \\
\text { OBSERVATION }\end{array}$ & MEAN & $\begin{array}{l}\text { STANDARD } \\
\text { VARIABLES }\end{array}$ & MIN & MAX \\
\hline $\ln \left(I M P C A P_{i j t}\right)$ & 1,392 & 8.698 & 3.929 & -3.963 & 16.834 \\
\hline $\ln \left(G D P c u_{i t}\right)$ & 1,479 & 26.518 & 0.796 & 25.282 & 27.672 \\
\hline $\ln \left(G D P c u_{j t}\right)$ & 1,453 & 25.733 & 1.789 & 19.901 & 30.654 \\
\hline $\ln \left(\boldsymbol{p o p}_{i t}\right)$ & 1,479 & 19.221 & 0.115 & 19.016 & 19.405 \\
\hline $\ln \left(\right.$ pop $\left._{j t}\right)$ & 1,476 & 17.073 & 1.582 & 13.074 & 21.0545 \\
\hline $\ln \left(\right.$ distw $\left._{i j t}\right)$ & 1,479 & 8.847 & 0.720 & 6.921 & 9.871 \\
\hline $\ln \left(\right.$ Tariff $\left._{i j t}\right)$ & 1,037 & 1.977 & 0.878 & 0 & 4.9061 \\
\hline $\ln \left(E R_{j t}\right)$ & 1,446 & 2.825 & 2.477 & 0.0000296 & 10.618 \\
\hline FTA & 1,479 & 0.100 & 0.300 & 0 & 1 \\
\hline CRISIS & 1,479 & 0.138 & 0.345 & 0 & 1 \\
\hline
\end{tabular}

As mentioned above, this study aims to identify the factors which determine the capital goods imports in Indonesia. Given the variables used in this study, the hypothesis will be as follows:

H1: Indonesia GDP, Trading Partners GDP, Indonesia Population, Trading Partners Population, Geographical Distance, Tariffs, Exchange Rates, Free Trade Agreement, and Crisis Occurance are simultaneously determined capital goods import value of Indonesia. To confirm the hypothesis, the model specification to identify the factors influencing capital goods imports in Indonesia to its trading partners and the trade efficiency will be as follows.

$$
\begin{aligned}
& \ln \left(I M P C A P_{i j t}\right)=\alpha_{1}+\alpha_{2} \ln \left(\text { GDPCu }_{i t}\right)+\alpha_{3} \ln \left(G D P c u_{j t}\right)+\alpha_{4} \ln \left(\text { pop }_{i t}\right)+\alpha_{5} \ln \left(\text { pop }_{j t}\right)+ \\
& \alpha_{6} \ln \left(\text { distw }_{i j t}\right)+\alpha_{7} \ln \left(\text { Tariff }_{i j t}\right)+\alpha_{8} \ln \left(E R_{j t}\right)+\alpha_{9} F T A+\alpha_{10} \text { Crisis }_{t}++\left(v_{t}-u_{t}\right) \\
& \text { where: }
\end{aligned}
$$

$I M P C A P_{i j t}$ is Indonesia's capital goods import values from economy $\mathrm{j}$ at time $\mathrm{t} ; G D P c u_{i t}$ and $G D P c u_{j t}$ indicate Indonesia and economy $\mathrm{j}$ GDP respectively at time $\mathrm{t} ; p_{i t}$ and $p o p_{j t}$ indicate the population of Indonesia and economy $\mathrm{j}$ respectively at time $\mathrm{t}$; distw $w_{i j t}$ is the distance between Indonesia and economy $\mathrm{j}$; Border Tariff $f_{i j t}$ is a tariff applied to Indonesia by economy $\mathrm{j}$, using applied weighted average (AHS); $E R_{j t}$ indicates economy j's official exchange rate; FTA is a dummy variable indicating the membership of FTA with the value is 1 when the economy $\mathrm{j}$ is the member of FTA, and 0 otherwise; Crisis is a dummy variable shows the crisis occurrence, with the value is 1 for Asian Financial Crisis in 1998-1999 and Global Financial Crisis in 2007-2008, and 0 otherwise. The term $v_{t}$ is the random errors; $u_{t}$ is the onesided error term including the country-specific constraint impacts.

Table 3 presents the data estimation results of Indonesia's capital good import values applying the SFGA methods. Indonesia's economic size (GDP) has a significant positive impact on capital product imports. It means that the capital product imports are expected to increase when Indonesia's economic size gets higher. It may indicate that when Indonesia's GDP increases, the Indonesian income gets higher, and thus Indonesia can have more capital goods imports.

The trading partner's GDP, which is used as a proxy of the total production in a country, may also have significant positive effects on the capital goods imports. It shows that a 1 percent increase of GDP of Indonesia's trading partners can improve the capital product imports by 1.07 percent. The possible explanation is that when the GDP of economy $\mathrm{j}$ gets higher, its production will be larger and thus enhancing the capital good supply in the global market, which lowers the price. Therefore, Indonesia's total imports are higher. 
Table 3 Regression result

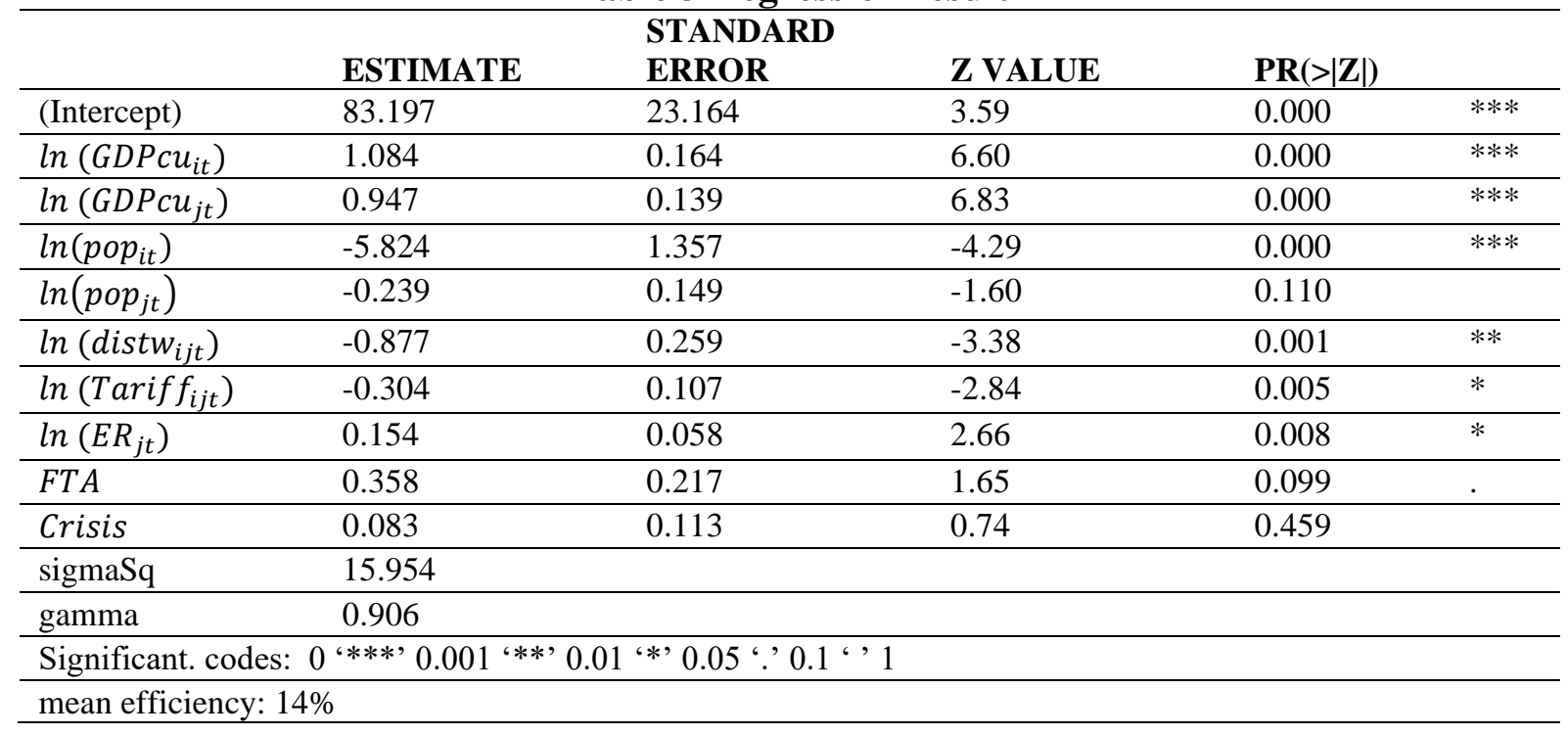

Furthermore, Indonesia's population may have significant negative effects on the capital goods imports, but the impacts of the trading partner's population are negative but not significant. In terms of Indonesia's population, the capital goods imports are expected to grow when the population increases. It may suggest that a larger population in Indonesia, capturing the number of production factors, may enhance the output production, and thus the capital product imports decline.

On the other hand, the distance between countries may have negative and significant effects on the capital goods imports in Indonesia. Geographical distance is a standard measure for transportation costs. The major determinant hampering the trade flows between economies is the transportation cost since a country will require to spend a larger amount of money to have a trade with a distant country (Kepaptsoglou et al., 2010). Furthermore, the impact of the exchange rate on capital good import values is positive and significant. The coefficient of 0.154 indicates that the 1 percent increase in the exchange rate reflecting the occurrence of Indonesia's currency appreciation, may enhance capital good import values by about 15.4 percent. It may suggest that the Rupiah appreciation will enhance the total imports. The tariff may have significant negative impacts on the capital goods imports in Indonesia. This is because the tariff may impose a higher cost for an economy to import and thus reduce the import values.

The impact of FTA on the capital goods imports in Indonesia is significantly positive. It means that Indonesia has higher capital goods imports with AFTA dan FTA-plus-one countries compared to remaining economies. It may suggest the trade corporation may have good impacts on the capital goods imports in Indonesia. It is in line with the previous studies. the regional cooperation through FTA can promote the trade flows between country members (Frankel \& Rose, 2000)

Next, the effects of country-specific constraints on capital product imports will be measured by sigma-squared (s2), gamma, and eta coefficient. A significant sigma-squared (s2) indicates that the potential capital products imports may alter about its average. Therefore, it may suggest that there are changes in potential capital good imports affected by the countryspecific constraints. The Gamma coefficient is also significant with the value of 0.896 . This may suggest that that behind the border constraints can explain 89.59 percent of the variation. However, an insignificant eta coefficient shows that there is not enough evidence to conclude that the impacts of country-specific characteristics have enhanced. 


\section{JURNALKU}

Volume 1 No. 3, September 2021

According to the Trade Efficiency in Appendix 2, Indonesia may still have a significant gap in its actual and potential capital good imports. The value of trade efficiency between Indonesia and 51 countries ranges between 0.01 percent and 79.97 percent. The trade realization from Panama is the highest among other countries, which is 79.97 percent. However, the estimated total mean trade efficiency is only about 14.00 percent, which may indicate the existence of significant trade differences in capital goods imports. According to Irhami (2007), the trade efficiency in Indonesia is affected by both openness and regional integration. Therefore, it will require further efforts to reduce the behind-the-border constraints stimulating the capital good imports in Indonesia so that it can achieve its potential level.

\section{SUMMARY \\ Conclusion}

The study explores Indonesia's capital goods imports from 51 trading partners from 1990 until 2018 using the SFGM method. This study aims to examine the major determinants of Indonesia's capital goods imports. The results indicate that some factors influencing the capital product imports positively are the economic and population size of the trading partners and the regional cooperation. Increases in these factors may boost the capital good imports. In contrast, the impacts of exchange rate and crisis on the capital good imports are significantly negative. The positive impacts of regional cooperation may indicate that such agreement may contribute to a reduction in behind-the-border constraints. However, the capital good imports may still have a gap between potential and actual imports indicating the presence of trade inefficiencies.

\section{Suggestion}

To enhance the trade efficiency, appropriate reforms to reduce behind-the-border constraints will be required to boost the performance of the capital good imports in Indonesia. However, identification of these specific constraints resulting in a trade gap in capital good imports in Indonesia is not covered in this study and thus may require further research.

\section{REFERENCES}

Alam, Md. M., Uddin, Md. G. S., \& Taufique, K. Md. R. (2009). Import Inflows of Bangladesh: the Gravity Model Approach. International Journal of Economics and Finance, 1(1). https://doi.org/10.5539/ijef.v1n1p131

Asean. (2016). The ASEAN Free Trade Area (AFTA). In Asociation of Southeast Asian Nation (Vol. 18, Issue 2).

Badan Kebijakan Fiskal. (2012). Laporan Hasil Kajian Free Trade Agreement (FTA) dan Economic Partnership Agreement (EPA), dan Pengaruhnya terhadap Arus Perdagangan dan Investasi dengan Negara Mitra Pusat Kebijakan Regional dan Bilateral.

Frankel, J. A., \& Rose, A. K. (2000). Estimating the Effect of Currency Unions on Trade and Output. NBER Working Paper Series, 3(7857, (August)).

Irhami, M. (2007). Stochastic Gravity Model and Trade Efficiency for Indonesia. In Economics and Finance in Indonesia (Vol. 55, Issue 2).

Kahfi, A. S. (2016). DETERMINANTS OF INDONESIA'S EXPORTS OF MANUFACTURED PRODUCTS: A PANEL DATA ANALYSIS. Buletin Ilmiah Litbang Perdagangan, 10(2). https://doi.org/10.30908/bilp.v10i2.54

Kalirajan, K. (2007). Regional cooperation and bilateral trade flow: An empirical measurement of resistance. International Trade Journal, 21(2). https://doi.org/10.1080/08853900701266555

Kalirajan, K. (2008). Gravity model specification and estimation: Revisited. Applied Economics Letters, 15(13). https://doi.org/10.1080/13504850600993499 


\section{JURNALKU}

Volume 1 No. 3, September 2021

Kepaptsoglou, K., Karlaftis, M. G., \& Tsamboulas, D. (2010). The Gravity Model Specification for Modeling International Trade Flows and Free Trade Agreement Effects: A 10-Year Review of Empirical Studies !2009-07-09 !2010-01-28 !2010-04-22 ! The Open Economics Journal, 3(1). https://doi.org/10.2174/1874919401003010001

Ma, Y. (2015). An Analysis of the Determinants of U.S. Imports Using a Gravity Model Approach Major Research Paper.

Miankhel, A. K., Kalirajan, K., \& Thangavelu, S. M. (2014). Australia's export potential: An exploratory analysis. Journal of the Asia Pacific Economy, 19(2). https://doi.org/10.1080/13547860.2013.820472

Noviyani, D. S., NA, W., \& Irawan, T. (2019). Indonesian Export Efficiency: A Stochastic Frontier Gravity Model Approach. International Journal of Scientific Research in Science, Engineering, and Technology. https://doi.org/10.32628/ijsrset1196190

Thirlwall. (2001). Economics of development.

tri wahyudi, setyo, \& Saras Anggita, R. (2015). The Gravity Model of Indonesian Bilateral Trade. International Journal of Social and Local Economic Governance, 1(2). https://doi.org/10.21776/ub.ijleg.2015.001.02.9

Wahyuningsih, D. (2021). Trade flow of manufacturing sector and foreign direct investment in ASEAN economic integration: the gravity model of trade. Jurnal Perspektif Pembiayaan Dan Pembangunan Daerah, 8(6). https://doi.org/10.22437/ppd.v8i6.10289

Wong, C. K. K., Liew, V. K. sen, \& Affendy Arip, M. (2017). The impact of ASEAN free trade area on intra-ASEAN manufacturing trade. International Journal of Business and Society, 18(3).

World Bank. (2018). Strengthening competitiveness.

World Bank. (2020). World Integrated Trade Solution (WITS)|Data on Export, Import, Tariff, NTM. World Integrated Trade Solution. 


\section{JURNALKU}

Volume 1 No. 3, September 2021

\section{Appendix 1}

The 51 Top Trading Partners of Indonesia's Capital Goods Imports

\begin{tabular}{|c|c|c|c|}
\hline NO & COUNTRY & NO & COUNTRY \\
\hline 1 & Argentina & 26 & Malaysia \\
\hline 2 & Australia & 27 & Mexico \\
\hline 3 & Azerbaijan & 28 & Myanmar \\
\hline 4 & Bangladesh & 29 & New Zealand \\
\hline 5 & Brazil & 30 & Nigeria \\
\hline 6 & Cambodia & 31 & Oman \\
\hline 7 & Canada & 32 & Pakistan \\
\hline 8 & Chile & 33 & Panama \\
\hline 9 & China & 34 & Papua New Guinea \\
\hline 10 & Colombia & 35 & Peru \\
\hline 11 & Czech Republic & 36 & Philippines \\
\hline 12 & Denmark & 37 & Poland \\
\hline 13 & East Timor & 38 & Qatar \\
\hline 14 & Ecuador & 39 & Russian Federation \\
\hline 15 & Egypt & 40 & Saudi Arabia \\
\hline 16 & Ghana & 41 & Singapore \\
\hline 17 & Greece & 42 & South Africa \\
\hline 18 & Hong Kong & 43 & Sri Lanka \\
\hline 19 & India & 44 & Sweden \\
\hline 20 & Iran & 45 & Switzerland \\
\hline 21 & Japan & 46 & Thailand \\
\hline 22 & Kenya & 47 & Turkey \\
\hline 23 & Korea & 48 & United Arab Emirates \\
\hline 24 & Kuwait & 49 & United Kingdom \\
\hline 25 & Lebanon & 50 & United States of America \\
\hline & & 51 & Vietnam \\
\hline
\end{tabular}




\section{JURNALKU}

Volume 1 No. 3, September 2021

\section{Appendix 2}

Trade Efficiency (\%) and Indonesia means import of capital products (US\$ million)

\begin{tabular}{l|l|l|l}
\hline COUNTRY & TECHNICAL & COUNTRY & TECHNICAL \\
& EFFICIENCY (\%) & & EFFICIENCY (\%) \\
\hline Panama & 79.97 & United Arab Emirates & 3.21 \\
China & 74.06 & Greece & 2.42 \\
Thailand & 70.63 & Papua New Guinea & 2.04 \\
United States of America & 60.95 & Argentina & 1.82 \\
Malaysia & 59.54 & Pakistan & 1.50 \\
Sweden & 54.03 & Ecuador & 0.91 \\
Japan & 40.94 & Egypt & 0.70 \\
Singapore & 35.53 & Russian Federation & 0.61 \\
Korea & 23.28 & Sri Lanka & 0.55 \\
United Kingdom & 22.16 & Chile & 0.50 \\
Brazil & 22.13 & Bangladesh & 0.32 \\
India & 21.53 & Saudi Arabia & 0.17 \\
Canada & 19.60 & East Timor & 0.15 \\
Australia & 17.46 & Ghana & 0.13 \\
Switzerland & 17.28 & Peru & 0.11 \\
Philippines & 12.39 & Myanmar & 0.11 \\
Hong Kong & 12.24 & Cambodia & 0.09 \\
Denmark & 10.39 & Oman & 0.08 \\
Mexico & 9.40 & Kenya & 0.08 \\
South Africa & 7.58 & Nigeria & 0.07 \\
Vietnam & 7.51 & Colombia & 0.04 \\
Czech Republic & 7.46 & Lebanon & 0.03 \\
Poland & 5.00 & Iran & 0.03 \\
Turkey & 3.77 & Aatar & 0.01 \\
New Zealand & 3.30 & \\
& & \\
\hline
\end{tabular}

